\title{
Upaya Meningkatkan Keterampilan Teknik Dasar Tendangan Mawashi-Geri Beladiri Karate Menggunakan Metode Drill Bagi Karate Inkado
}

\author{
Novi Dwi Sasmita, Oni Bagus Januarto*, Ari Wibowo Kurniawan \\ Universitas Negeri Malang, Jl. Semarang No. 5 Malang, Jawa Timur, Indonesia \\ Novi Dwi Sasmita, Surel: oni.bagus.fik@um.ac.id
}

Paper received: 5-1-2022; revised: 22-1-2022; accepted: 29-1-2022

\begin{abstract}
The mawashi-geri kick is a basic technique of kicking in karate which is used to attack almost all parts of the body. For this reason, it needs to be trained using the drill method so that it can be maximized. The purpose of this study was to improve the kicks skills of mawashi-geri karate self-defense in Inkado karate. This research is a sports action research that uses descriptive qualitative and quantitative descriptive methods. The results of the research that have been done show that the success rate of Inkado karate in cycle 1 is $51.39 \%$, while in cycle 2 it is $69.99 \%$. Based on the results of cycles 1 and 2, there was an increase of $18.6 \%$. Based on the results of the study, it can be concluded that using the drill training method can improve the kicks skills of mawashi-geri karate martial arts in Inkado karate
\end{abstract}

Keywords: mawashi-geri kicks; karate; drill metode

\begin{abstract}
Abstrak
Tendangan mawashi-geri merupakan teknik dasar tendangan di dalam beladiri karate yang digunakan untuk menyerang, hampir seluruh bagian tubuh. Untuk itu perlu dilatih dengan menggunakan metode drill agar bisa maksimal. Tujuan dari penelitian ini adalah untuk meningkatkan keterampilan tendangan mawashi-geri beladiri karate pada karate-ka Inkado. Penelitian ini merupakan penelitian tindakan olahraga yang menggunakan metode deskriptif kualitatif dan deskripstif kuantitatif. Hasil dari penelitian yang sudah dilakukan menunjukkan bahwa tingkat keberhasilan pada karate-ka Inkado pada siklus 1 sebesar 51,39\%., sedangkan pada siklus 2 sebesar 69,99\%. Berdasarkan hasil dari siklus 1 dan 2 mengalami peningkatan sebesar 18,6\%. Berdasarkan hasil penelitian dapat disimpulkan bahwa dengan menggunakan metode drill latihan dapat meningkatkan keterampilan tendangan mawashi-geri beladiri karate pada karate-ka Inkado
\end{abstract}

Kata kunci: tendangan mawashi-geri; karate; metode drill

\section{Pendahuluan}

Memiliki tubuh yang sehat dan bugar tentu menjadi keinginan bagi setiap orang, terlebih lagi jika mempunyai tubuh yang sehat dapat menunjang dalam melakukan aktivitas fisik dengan prima. Banyak cara yang dapat digunakan untuk memperoleh tubuh yang sehat, salah satunya yaitu dengan rutin melakukan olahraga. Menurut Yuliatin (2012) "olahraga adalah serangkaian gerak raga yang teratur dan terencana untuk memelihara gerak (meningkatkan kualitas hidup)". Olahraga itu sendiri tentu sangat erat kaitannya dengan kehidupan manusia, karena dengan olahraga banyak manfaat yang bisa diperoleh di dalamnya. Dan olahraga untuk sekarang ini sudah menjadi salah satu kebutuhan hidup bagi manusia untuk mencapai kesehatan jasmani, di dalam olahraga ini juga memiliki semboyan tersendiri (tanda) untuk bisa meningkatkan semangat masyarakat, semboyan ini berbunyi "memasyarakatkan olahraga dan mengolahragakan masyarakat" ini samboyan untuk memotifasi masyarakat untuk mengupayakan masyarakat Indonesia yang gemar berolahraga (Kurniawan A.W, 2014). Jadi 
menurut peneliti Di Indonesia ini banyak cabang olahraga yang diakui oleh KONI menurut peneliti yang diketahui ada beberapa cabang olahraga, diantaranya adalah cabang olahraga sepakbola, sepak takraw, bolavoli, olahraga air, bulutangkis, bolabasket, dan juga ada beladiri. Peneliti mengambil penelitian di salah satu cabang olahraga yang ada di Indonesia, salah satunya adalah cabang olahraga beladiri. Olahraga beladiri ini banyak sekali contohnya yang penulis ketahui, seperti beladiri silat, taekwondo, wushu, judo, karate, dan masih banyak lagi.

Wijaya (2015) menjelaskan bahwa "karate adalah seni beladiri yan berasal dari Jepang yang memiliki dua kata yakni "kara" yang memiliki arti kosong dan "te" yang berarti tangan, jadi karate adalah seni beladiri yang menggunakan tangan kosong". Nenggar (2014) menyatakan bahwa tendangan mawashi-geri mempunyai nilai yang baik pada saat digunakan pertandingan, karena itu juga karateka harus mempunyai kekuatan dan kelentukan agar bisa melakukan tendangan mawashi-geri dengan baik dan sempurna.

Pada semua klub atau Dojo pasti selalu menginginkan karate-ka - karate-kanya memiiliki prestasi yang membanggakan, tidak terkecuali juga dengan Dojo Inkado Denbekang V-44-02 Mojokerto. Dojo Karate Inkado yang beralamat di Jalan Pahlawan, 12a, Mojokerto ini adalah salah satu dari sekian banyak klub atau Dojo karate yang ada di Mojokerto. Klub atau Dojo ini sudah berdiri sejak tahun 2009 dan memiliki total karateka sebanyak 15 karateka diantaaranya 7 Laki-laki dan 8 Perempuan. Menurut Bapak Syamsul selaku pelatih di Dojo ini mengatakan bahwa karateka ini yang rutin untuk berlatih di setiap minggunya.

Pada analisis kebutuhan yang dilakukan oleh peneliti pada hari Sabtu dan Minggu, tanggal 12-13 Oktober peneliti melakukan observasi dengan mengamati setiap gerakan yang digunakan pada saat pertandingan karate yang diadakan oleh UBALAN CUP 2019 yang bertempat di Wisata Ubalan Pacet, Kabupaten Mojokerto. Pada saat itu peneliti mengamati pertandingan tersebut, karateka Inkado Denbekang V-44-02 Mojokerto ini beberapa ada yang mengikuti kejuaraan tetapi tidak semua hanya beberapa saja, setelah peneliti mengamati karateka Inkado Denbekang V-44-02 Mojokerto ini banyak yang melakukan serangan tendangan tetapi tidak ada yang diambil oleh wasit juri, dari situ peneliti menemukan permasalahan awal. Dengan adanya tindak lanjut untuk memperjelas dan memperkuat masalah yang ada, peneliti melakukan observasi pada saat latihan berlangsung di Inkado Denbekang V-44-02 Mojokerto pada hari Kamis, 24 Oktober 2019 yang dimaksud untuk memperoleh data awal observasi pada karate-ka karate di Inkado Denbekang V-44-02 Mojokerto. Didapatkan kesimpulan dari hasil observasi ternyata banyak karate-ka yang mengalami kesulitan pada saat melakukan tendangan mawashi-geri beladiri karate. Ditambah lagi dengan adanya hasil wawancara dengan pelatih bahwa tendangan mawashi-geri merupakan salah satu tendangan yang sulit dikuasai bagi karateka di Dojo Inkado Denbekang V-44-02 Mojokerto ini. Pada hari Senin, 28 Oktober 2019 peneliti melakukan observasi awal dengan dibantu salah satu pelatih dari luar perguruan untuk bertindak sebagai observer untuk mengamati gerakan. Disini peneliti melibatkan 15 karate-ka yang nantinya mereka akan bermain pasangan dengan yang satu memegang target dan satu melakukan dalam durasi waktu 1 menit karateka bisa mencapai teknik dasar tendangan mawashi-geri sudah benar atau belum pada saat melakukan teknik dasar tendangan tersebut.

Berdasarkan dari hasil tes karateka keseluruhan ini, peneliti mendapatkan hasil tes pengamatan teknik dasar tendangan karate. Didalam hasil tes keseluruhan teknik dasar tendangan karate ini didapatkan paparan data hasil dari keseluruhan karate-ka yang 
melakukan tes teknik dasar tendangan karate. Diantaranya mendapatkan hasil keseluruhan sebanyak 449 kali dalam waktu 1 menit dengan didapatkan hasil tendangan yang benar sebanyak 266 dengan persentase 59,2\% dan tendangan yang salah sebanyak 183 dengan persentase $40,7 \%$. Pada tendangan yoko-geri kayage yang dilakukan sebanyak 456 kali dalam 1 menit didapatkan hasil tendangan yang benar sebanyak 261 dengan persentase 57,2\% dan tendangan yang salah sebanyak 195 dengan persentase 42,7\%. Pada tendangan mawashi-geri yang dilakukan sebanyak 419 kali dalam waktu 1 menit didapatkan hasil tendangan yang benar sebanyak 187 dengan persentase 44,6\% dan tendangan yang salah sebanyak 232 dengan persentase 55,5\%. Pada tendangan yoko-geri kekome yang dilakukan sebanyak 409 kali dalam waktu 1 menit didapatkan hasil tendangan yang benar sebanyak 232 dengan persentase $56,7 \%$ dan tendangan yang salah sebanyak 177 dengan persentase 43,2\%. Pada tendangan ushirogeri yang dilakukan sebanyak 263 kali dalam waktu 1 menit didapatkan hasil tendangan yang benar sebanyak 137 dengan persentase 52,0\% dan tendangan yang salah sebanyak 126 dengan persentase $47,9 \%$.

Pada hari Kamis 31 Oktober 2019 dilakukan tes keterampilan tendangan mawashi-geri beladiri karate yang berfungsi untuk melatih kemampuan karate-ka dalam melakukan tendangan mawashi-geri karate di Inkado Denbekang V-44-02 Mojokerto terhadap 15 karateka dapat diketahui bahwa masih banyak yang mengalami kesulitan pada sikap awalan yang meliputi: (1) Berdiri dengan posisi kuda-kuda zenkutsu dachi, angkat kaki bagian belakang dan sejajar dengan posisi tubuh, dan tidak melewati garis tubuh depan, (2) Tumit kaki yang diangkat harus menyentuh bagian belakang paha, (3) Tubuh tegak serta lutut kaki pendukung tegak lurus sementara kaki belakang yang diangkat dibengkokkan kearah target serangan dan dipatkan hasil sebanyak 51,1\% karate-ka mengalami kesulitan yang terbagi menjadi 7 karateka kesulitan pada sikap awalan tahap 1, 5 karate-ka pada sikap awalan tahap 2, dan 11 karateka pada sikap awalan tahap 3. Sedangkan $48,9 \%$ karateka tidak mengalami kesulitan yang terbagi menjadi 8 karateka pada sikap awalan tahap 1,10 karateka pada sikap awalan 2, dan 4 karateka pada sikap awalan 3. Kemudian pada sikap saatn menendang yang meliputi: (1) Posisi rotasi pinggul atau memutar pinggul harus sangat cepat, ketika gerakan pinggul dimulai, kaki dilecutkan dengan kecepatan maksimum, (2) Gerak patah keseimbangannya harus baik, dan gelombang kejutnya harus yang maksimal kepada target, (3) Ada kombinasi antara memutar pinggul dan kaki-kaki pendukung harus tertanam kuat pada tanah dan didapatkan hasil sebanyak 57,8 \% karate-ka mengalami kesulitan yang terbagi menjadi, 5 karate-ka pada sikap menendang tahap 1, 8 karate-ka pada sikap menendang tahap 2, dan 13 karate-ka pada sikap menendang tahap 3. Sedangkan sebanyak $42,2 \%$ karateka tidak mengalami kesulitan pada sikap menendang yang terbagi menjadi 10 karateka pada sikap menendang tahap 1, 7 karateka pada sikap menendang tahap 2, dan 2 karateka pada sikap menendang tahap 3. Lalu pada sikap akhiran yang meliputi : (1) Setelah menendang mawashi-geri dilakukan, pada akhirnya menarik kaki setelah mengeksekusi dilakukan pada sama pada saat melakukan tendangan harus kontrol dengan baik, (2) Kaki harus ditempatkan di tanah dengan cepat dan jangan menggantung, (3) Kembali pada posisi awal dengan posisi kuda-kuda zenkutsu dachi dan posisi siap lagi dan didapatkan hasil sebanyak $60 \%$ karate-ka mengalami kesulitan yang terbagi menjadi 7 karate-ka pada sikap akhiran tahap 1, 7 karate-ka pada sikap akhiran tahap 2, dan 13 karate-ka pada sikap akhiran tahap 3. Sedangkan sebanyak 40\% karateka tidak mengalami kesulitan pada sikap akhiran yang terbagi menjadi 8 karateka pada sikah akhiran tahap1, 8 karateka pada sikap akhiran tahap 2, dan 13 karateka pada sikap akhiran tahap 3. 
Dari hasil ini tes keterampilan tendangan mawashi-geri baladiri karate yang sudah dilakukan oleh peneliti bisa disimpulkan bahwasannya masih banyak karateka di Inkado Denbekang V-44-02 Mojokerto yang mengalami kesulitan dan kesalahan pada tendangan mawashi-geri dari mulai sikap awalan, sikap menendang, dan pada sikap akhiran. Selain itu hasil penyebar angket pada karate-ka dan wawancara terhadap pelatih diketehui bahwa sebanyak 14 karate-ka (93,3\%) menyatakan bahwa tendangan mawashi-geri merupakan tendangan yang sulit dilakukan dalam teknik dasar tendangan karate, 13 karate-ka (86,6\%) menyatakan bahwa mereka membutuhkan latihan tendangan mawashi-geri pada latihan karate, dan 15 karate-ka (100\%) sepakat menyatakan bahwa mereka setuju bila diadakan metode drill pada saat latihan tendangan mawashi-geri beladiri karate.

Dari pelatih sendiri juga menyatakan bahwa karateka Inkado Denbekang V-44-02 Mojokerto ini memang banyak yang mengalami kesulitan pada saat melakukan tendangan mawashi-geri tersebut, selain itu menurut pelatih memang belum ada selama ini yang menerapkan variasi model latihan teknik dasar tendangan mawashi-geri dengan metode drill pada saat latihan. Hal ini terlihat pada saat latihan berlangsung banyak karate-ka yang melakukan tendangan mawashi-geri yang masih kurang baik dalam melakukan gerakan yang benar. Oleh karena itu agar dapat tercapai keterampilan pada tendangan mawashi-geri yang baik dan benar harus ada sesuatu yang bisa meningkatkan keterampilan tendangan tersebut untuk bisa menjadi baik dan benar, adapun solusi untuk bisa mengatasi masalah ini. Dalam hal ini pelatih ingin memberikan suatu solusi untuk merencanakan latihan tendangan mawashigeri secara berulang-ulang atau dengan metode drill untuk membenahi suatu keterampilan teknik dasar tendangan tersebut menjadi baik dan benar.

Berdasarkan latar belakang yang sudah diuraikan di atas, peneliti perlu melakukan penelitian yang bertujuan untuk dapat meningkatkan keterampilan tendangan mawashi-geri menggunakan metode drill untuk karate-ka yang diadakan di Inkado Denbekang V-44-02 Mojokerto.

\section{Metode}

Pada penelitian kali ini peneliti menggunakan rancangan penelitian tindakan olahraga (PTO). Metode penelitiannya menggunakan deskriptif kualitatif dan deskripsi kuantitatif. Pengumpulan data dilakukan menggunakan observasi, wawancara, angket dan tes keterampilan. Sebelum melakukan penelitian, peneliti terlebih dahulu melakukan observasi awal untuk mengetahui kekurangan dan kelebihan dari para atlet, kemudian peneliti juga melakukan wawancara dengan pelatih untuk lebih mengetahui permasalahan yang terjadi.

Selanjutnya peneliti melakukan penyebaran angket kepada atlet. Pada saat proses penelitian penilaian dilakukan dengan cara mencatat setiap pukulan yang dilakukan oleh atlet, meliputi sikap persiapan, sikap memukul dan sikap lanjutan. Kemudian dari hasil penilaian tersebut dihitung menggunakan rumus persentase milik Sudijono (2008) yang sebagai berikut.

$$
\mathrm{P}=\frac{f}{N} x \mathbf{1 0 0} \%
$$

Keterangan:

$f \quad=$ frekuensi yang sedang dicari persentasenya

$\mathrm{N} \quad=$ number of cases (jumlah frekuensi/banyaknya individu)

$\mathrm{P} \quad=$ angka persentase 
Kemudian hasil dari tes keterampilan tendangan mawashi-geri karate dapat dikatakan berhasil jika sudah melebihi 65\%. Penelitian ini dilaksanakan di Inkado Denbekang V-44-02 Mojokerto dengan subjek penelitian sebanyak 15 karate-ka yang terdiri dari 7 laki-laki dan 8 perempuan. Penelitian ini menggunakan 2 siklus, dimana pada tiap siklusnya terdapat 5 kali pertemuan. Akan tetapi siklus 2 hanya akan dilakukan apabila pada siklus 1 tidak mencapai nilai $65 \%$.

\section{Hasil dan Pembahasan}

Hasil tes keterampilan tendangan mawashi-geri karate pada karateka Inkado Denbekang V-44-02 Mojokerto dalam setiap siklusnya akan dijelaskan sebagai berikut.

Tabel 1. Hasil tes keterampilan tendangan mawashi-geri karate pada siklus 1 dan 2

\begin{tabular}{|c|c|c|c|c|c|c|c|c|c|c|}
\hline \multicolumn{11}{|c|}{ Gerakan Teknik Dasar Tendangan Mawashi-Geri Karate } \\
\hline \multicolumn{11}{|c|}{ Tendangan ke- } \\
\hline & 1 & 2 & 3 & 4 & 5 & 6 & 7 & 8 & 9 & 10 \\
\hline \multicolumn{11}{|l|}{ Siklus 1} \\
\hline \multicolumn{11}{|l|}{ Observer } \\
\hline Pertemua & 35,5 & 40,0 & 40,0 & 42,2 & 40,0 & 44,4 & 44,4 & 46,6 & 48,8 & 53,3 \\
\hline n 1 & 6 & 0 & 0 & 2 & 0 & 4 & 4 & 7 & 9 & 3 \\
\hline Pertemua & 42,2 & 46,6 & 44,4 & 46,6 & 46,6 & 48.8 & 51,1 & 51,1 & 51,1 & 60,0 \\
\hline n 2 & 2 & 7 & 4 & 7 & 7 & 9 & 1 & 1 & 1 & 0 \\
\hline Pertemua & 41,6 & 44,4 & 44,4 & 50,0 & 44,4 & 47,2 & 50,0 & 52,7 & 50,0 & 58,3 \\
\hline n 3 & 7 & 4 & 4 & 0 & 4 & 2 & 0 & 8 & 0 & 3 \\
\hline Pertemua & 50,0 & 52,3 & 54,7 & 54,7 & 57,1 & 54,7 & 57,1 & 59,5 & 61,9 & 61,9 \\
\hline n 4 & 0 & 8 & 6 & 6 & 4 & 6 & 4 & 2 & 0 & 0 \\
\hline Pertemua & 53,3 & 55,5 & 55,5 & 57,7 & 55,5 & 60,0 & 60,0 & 62,2 & 66,6 & 71,1 \\
\hline n 5 & 3 & 6 & 6 & 8 & 6 & 0 & 0 & 2 & 7 & 1 \\
\hline \multicolumn{11}{|l|}{ Siklus II } \\
\hline \multicolumn{11}{|l|}{ Observer } \\
\hline Pertemua & 57,7 & 57,7 & 55,5 & 55,5 & 60,0 & 62,2 & 62,2 & 64,4 & 75,5 & 84,4 \\
\hline n 1 & 8 & 8 & 6 & 6 & 0 & 2 & 2 & 4 & 6 & 4 \\
\hline Pertemua & 58,9 & 53,8 & 69,2 & 53,8 & 69,2 & 64,1 & 66,6 & 66,6 & 79,4 & 69,2 \\
\hline n 2 & 7 & 5 & 3 & 5 & 3 & 0 & 7 & 7 & 9 & 3 \\
\hline Pertemua & 57,1 & 54,7 & 59,5 & 52,3 & 71,4 & 69,0 & 80,9 & 78,5 & 80,9 & 88,1 \\
\hline n 3 & 4 & 6 & 2 & 8 & 3 & 5 & 5 & 7 & 5 & 0 \\
\hline Pertemua & 68,8 & 66,6 & 71,1 & 73,3 & 68,8 & 68,8 & 77,7 & 82,2 & 73,3 & 86,6 \\
\hline n 4 & 9 & 7 & 1 & 3 & 9 & 9 & 8 & 2 & 3 & 7 \\
\hline Pertemua & 73,3 & 66,6 & 73,3 & 68,8 & 77,7 & 77,7 & 77,7 & 86,6 & 88,8 & 91,1 \\
\hline n 5 & 3 & 7 & 3 & 9 & 8 & 8 & 8 & 7 & 9 & 1 \\
\hline \multicolumn{7}{|c|}{ Persentase Ketuntasan Siklus 1} & \multicolumn{4}{|c|}{51,39} \\
\hline \multicolumn{7}{|c|}{ Persentase Ketuntasan Siklus II } & \multicolumn{4}{|c|}{69,99} \\
\hline
\end{tabular}

Berdasarkan sajian Tabel 1 dapat dilihat bahwa hasil tes keterampilan teknik dasar tendangan mawashi-geri karate pada karateka di Inkado Denbekang V-44-02 Mojokerto di siklus 1 sebesar 51,39\%. Hasil tersebut masih tergolong dalam kategori cukup saja, sedangkan untuk bisa dikatakan berhasil harus berada dalam kategori baik yaitu sebesar 67,00\%, sehingga perlu dilakukan siklus 2 untuk dapat menaikkan hasil tes keterampilan tendangan mawashi-geri karate. Seperti halnya pada siklus 2 yang mendapatkan hasil sebesar 69,99\% sehingga sudah bisa dikategorikan baik, jadi dapat disimpukan bahwa peneliti sudah 
menyelesaikan pada siklus 2 dikarenakan karate-ka sudah mencapai nilai yang dikategorikan baik, sehingga tidak perlu lagi dilaksanakan penelitian kembali.

Berdasarkan hasil pengamatan yang dilakukan pada pelaksanaan tindakan siklus 1 selama 5 kali pertemuan yang dilaksanakan pada tanggal 7 Maret 2020 - 19 Maret 2020 dimulai pukul 19.00-21.00 WIB dan siklus 2 dilaksanakan pada tanggal 14 Juni 2020 - 11 Juli 2020 dimulai pukul 07.00 - 09.00 dan juga 16.00 - 18.00 WIB di Inkado Denbekang V-44-02 Mojokerto dengan materi keterampilan teknik dasar tendangan mawashi-geri karate diperoleh hasil yang bisa dilihat pada Gambar 1 .

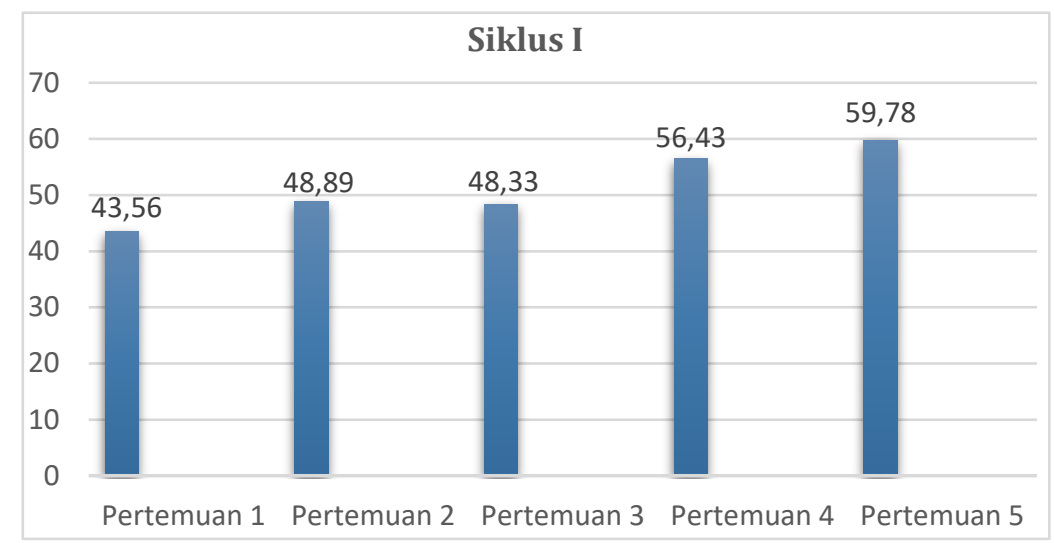

Gambar 1. Diagram Data Hasil Penialain Siklus 1

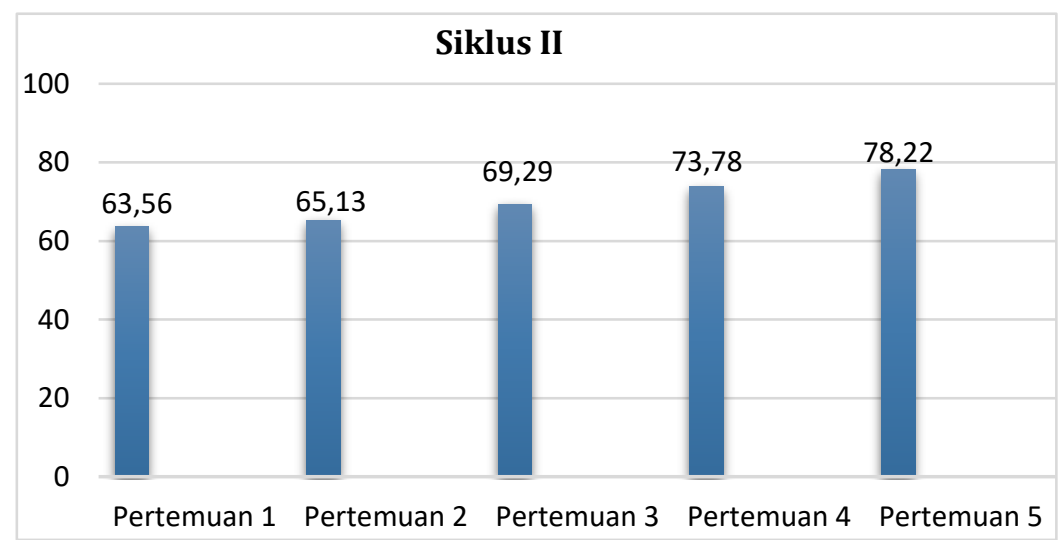

Gambar 2. Diagram Data Hasil Penialain Siklus 2

Dari hasil pengamatan Gambar 1 dan 2 dapat dilihat bahwa mengenai kriteria ketuntasan yang dimana dijelaskan bahwa jika melebihi nilai 65\% maka dikategorikan keberhasilannya baik dan dapat digunakan. Sementara hasil yang telah diperoleh peneliti mendapatkan hasil sebesar 69,99\% sehingga dapat disimpulkan didalam kategori baik. Dan hasil ini sehubung dengan hasil kategori "Baik" sehingga dapat digunakan metode drill latihan untuk meningkatkan keterampilan teknik dasar tendangan mawashi-geri beladiri karate pada karateka Inkado Denbekang V-44-02 Mojokerto.

\subsection{Perbandingan Siklus 1 san Siklus 2}

Setelah melaksanakan seluruh kegiatan pada siklus 1 dan siklus 2, peneliti dan pelatih melakukan refleksi. Hasil yang didapatkan mengenai keterampilan teknik dasar tendangan 
mawashi-geri beladiri karate pada karateka Inkado Denbekang V-44-02 Mojoketo dari siklus 1 ke siklus 2 mengalami peningkatan yang signifikan. Berikut adalah perbandingan siklus 1 dan siklus 2 yang dapat dilihat pada Tabel 3 .

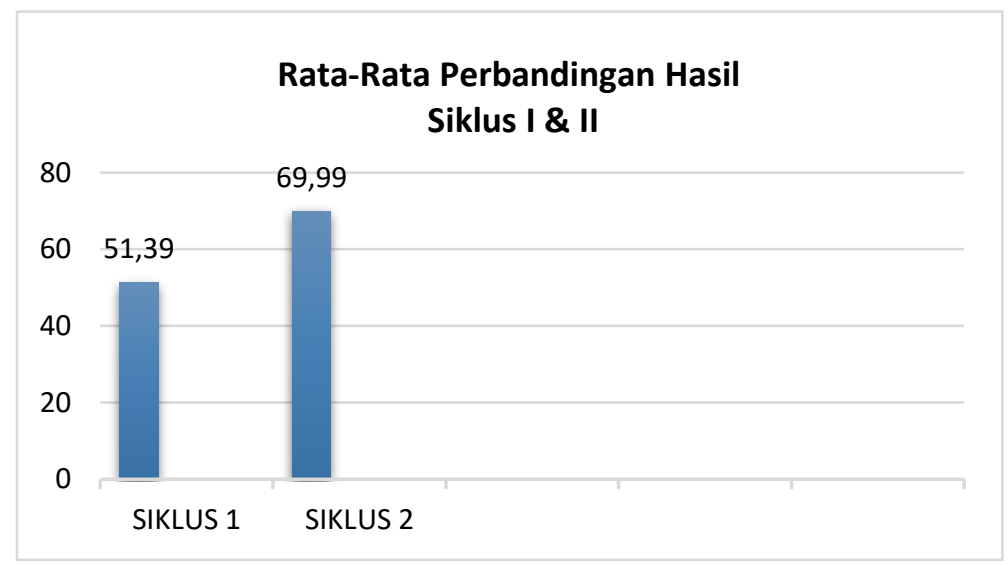

Gambar 3. Perbandingan Hasil Siklus 1 dan Siklus 2

\subsubsection{Hasil Perbandingan Dari Siklus 1 dan Siklus 2}

Berdasarkan hasil perbandingan dari siklus 1 dan siklus 2 yang terdapat pada Gambar 3 diatas maka dapat disimpulkan bahwa:

1. Pada siklus 1 dan siklus II terlihat persentase ketuntasan atlet yang dilakukan oleh observer mengalami peningkatan yang signifikan.

2. Peningkatan persentase ketuntasan jika dilihat dari pertemuan pertama siklus 1 hingga pertemuan siklus II sebesar $43,56 \%$ pada pertemuan pertama siklus 1 , sedangkan pada pertemuan terakhir siklus II sebesar 78,22\%.

3. Peningkatan persentase ketuntasan dari siklus 1 dan siklus II dikarenakan pada saat melakukan program latihan dengan metode drill karateka melakukannya dengan baik.

Dari hasil yang telah dipaparkan tersebut, dapat dilihat pada Gambar 3 mengenai kriteria ketuntasan yang mana disana dijelaskan bahwa jika melebihi nilai 65\% maka masuk dalam kategori baik dan dapat digunakan. Sementara hasil yang telah diperoleh peneliti mendapatkan hasil sebesar 69,99\% sehingga bisa dikatakan dalam kategori baik. Sehingga dapat disimpulkan bahwa dengan menggunakan metode drill latihan dapat meningkatkan keterampilan tendangan mawashi-geri karate pada karateka Inkado Denbekang V-44-02 Mojokerto. Di dalam teknik dasar tendangan ini juga ada beberapa teknik yaitu teknik penyerangan, dimana teknik itu ada beberapa contoh seperti mae geri, ushiro geri, dan juga mawashi geri (Hutanty, 2013). Seperti halnya peneliti mengambil penelitian tersebut disalah satu contoh tendangan tersebut ini adalah tendangan mawashi-geri.

\subsection{Pembahasan}

Karate merupakan cabang olaharaga beladiri dari negara Jepang, yang memiliki artian sebagai berikut, kata karate dalam kanji Jepang adalah "kara" berarti kosong dan "te" yang berarti tangan, jadi karate adalah cabang olahraga beladiri karate yang menggunakan tangan kosong. Karate ini pada dasarnya juga adalah ilmu beladiri dimana ilmu beladiri ini hanya 
memerlukan tenaga, fisik, dan cara berfikir dengan pengendalian emosi (Leiman. 2016). Menurut Riyadi (2018) karate merupakan salah satu cabang olahraga beladiri yang dipertandingkan dalam dua nomor, nomer tersebut adalah nomor kata dan nomor kumite. Sedangkan menurut Pion,dkk (2012) karate adalah seni beladiri yang ditandai dengan pukulan dan juga tendangan dari kedua tungkai atas dan bawah. Di dalam seni beladiri ini merupakan kelompok seni beladiri yang melibatkan aturan di dalam kompetisi terunamen, ada 5 jenis dengan tingkat kontak yaitu sebagai berikut: 1) kontak ringan atau sentuhan, 2) semi kontak, 3) knock down tanpa kontak penuh menyerang ke kepala, 4) knock down dengan serangan kontak penuh ke kepala, 5). Dan kontak penuh.

Menurut Zetaruk et al (2000) karate memiliki banyak manfaat diantaranya yaitu meningkatkan kedisplinan, kosentrasi mental, dan kondisi fisik, serta memiliki rasa kesenangan. Karate juga memiliki banyak variabilitas di antaranya seni beladiri, dan perbedaaan dalam filsafat pengajaran di dalam gaya apapun. Ada juga yang berpendapat bahwa di dalam semua beladiri, untuk mengetahui bagaimana mengelola barycentre yang tepat sangat penting, karena itu dimana ada titik seluruh massa dan berat tubuh manusia berkumpul, sama halnya dengan beladiri karate (Gianino. 2011).

Mawashi-Geri menurut Oyama (2006) mawashi-geri adalah tendangan yang melingkar dengan menggunakan punggung kaki dan tendangan mawashi-geri digunakan pada pertandingan kategori kumite. Purba (2017) menyatakan bahwa teknik dasar tendangan mawashi-geri adalah tendangan lurus yang dari arah samping dengan mengeksekusi dari berbagai sikap, dan ada beberapa metode pelaksanaan yang selalu konsisten dengan sudut mana saja yang sejajar dengan lantai ke arah 45 derajat ke atas. Budiwanto (2012) menjelaskan tujuan latihan teknik adalah: Untuk mempertinggi keterampilan gerakan teknik dan memperoleh otomatisasi gerakan teknik dalam suatu cabang olahraga. Chan (2012) mengatakan latihan merupakan aktivitas yang dilakukan secara sistematis dan terencana yang bertujuan untuk meningkatkan fungsional fisik dan psikis pelakunya.

Berdasarkan paparan data di atas dalam meningkatkan keterampilan teknik dasar tendangan mawashi-geri beladiri karate pada karateka Inkado Denbekang V-44-22 Mojokerto ini, maka diberikan perlakuan latihan mawashi-geri dengan menggunakan model latihan drill. Dimana peningkatan keterampilan menurut Sugiyanto (dalam Lumintuarso 2013) mengatakan bahwa, "untuk mencapai tingkat keterampilan tertentu membutuhkan waktu lamanya tidak sama pada setiap individu, tergantung pada bakat yang dimiliki". Talib (2018) menyatakan bahwa metode latihan drill memiliki pengaruh besar terhadap kecepatan mawashi-geri pada kohai Dojo inkado kodim 1304 kota gorontalo. Manullang \& Tambunan (2020) menyatakan bahwa "the effect of dill exercise methode against speed kick of mawahi-geri karate extracurricular's students at SMP Negeri 4 Palembang." artinya pengaruh metode latihan drill terhadap tendangan cepat siswa ekstrakurikuler mawashi-geri karate di SMP Negeri 4 Palembang. Di dalam latihan menurut Santana, dkk (2008), latihan merupakan program yang didalamnya mengkait dengan adanya integral dari setiap pelatih olahraga individu, berbeda dengan Harun, dkk (2017) latihan merupakan suatu kegiatan yang dilakukan supaya kemampuan dan keterampilan seseorang pemain dapat ditingkatkan dan meningkat, latihan ini harus dilakukan secara teratur dan sungguh-sungguh serta harus dilakukan secara berulang-ulang supaya bisa mencapai suatu tujuan yang di inginkan oleh seseorang pemain. 
Menurut Hamid (2012), metode latihan atau metode drill, juga biasa disebut dengan metode training merupakan metode yang digunakan untuk mengajar dalam upaya menanamkan berbagai kebiasaan atau keterampilan tertentu kepada para siswa. Majid (2015) menyatakan bahwa, drill juga secara denotatif merupakan tindakan untuk meningkatkan keterampilan dan kemahiran sebagai sebuah metode, drill adalah suatu pembelajaran siswa untuk mengembangkan keterampilan dan kemahiran serta dapat mengembangkan sikap dan kebiasaan. Menurut Diyanto (2019) metode drill ini memiliki suatu proses pembelajaran yang mempunyai kedudukan yang sangat penting dalam upaya pencapaian tujuan, karena metode ini merupakan suatu cara atau jalan yang ditempuh yang sesuai, dan serasi untuk menyajikan suatu hal, sehingga tercapainya suatu tujuan proses pembelajaran yang efektif dan efisien. Metode drill merupakan metode mengajar dengan memberikan suatu latihan-latihan atau suatu kegiatan yang dilakukan secara berulang-ulang kepada karateka untuk memeperoleh suatu keterampilan pada karateka (Suyanto, 2013). Dari beberapa tinjauan pustaka disimpulkan oleh penulis bahwa metode drill adalah suatu tindakan atau sesuatu kegiatan yang dilakukan secara berulang-ulang dan suatu pengajaran dengan melatih karateka atau peserta didik secara berulang untuk bisa mencapai suatu tujuan yang efektif dan efisien.

Peneliti ini juga mengkaji dua penelitian yang berhubungan dengan penelitian skripsi ini. penelitian sehubungan pertama. Andayani, (2017) menyimpulkan bahwa dengan menggunakan bentuk latihan teknik dasar mawashi-geri dengan model latihan drill yang bervariasi dapat meningkatkan keterampilan teknik dasar tendangan mawashi-geri karate, hanya saja model latihan yang digunakan untuk membedakannya. Sehingga hal ini memperkuat hasil penelitian dari peneliti bahwa dengan model latihan drill bervariasi yang terdapat klasifikasi baik pada setiap indikator sehingga untuk membiasakan karate-ka melakukan tendangan mawashi-geri dengan otomatisasi. Menurut Effendi (2015) latihan yang teratur dapat meningkatkan susunan maupun fungsi otot sehingga sistem kerja pada otot menjadi lebih efisien, efektif, dan menyebabkan seseorang tidak mudah kelelahan ataupun lelah dalam melakukan olahraga.

Penelitian sehubungan kedua Pratuningtyas, (2017) menyimpulkan bahwa dengan menggunakan latihan variasi dynamic balance dapat meningkatkan keterampilan tendangan mawashi-geri cabang olahraga beladiri karate. Di dalam model latihan drill yang digunakan peneliti ini, variasi model latihan yang digunakan oleh penliti juga memiliki unsur untuk melatih keseimbangan dalam melakukan teknik dasar tendangan mawashi-geri beladiri karate, hanya saja yang digunakan berbeda, sehingga hal ini memperkuat hasil penelitian dari peneliti bahwa model latihan drill yang terdapat unsur melatih keseimbangan dapat meningkatkan teknik dasar tendangan mwashi-geri olahraga beladiri karate. Ada juga yang berpendapat bahwa di dalam semua beladiri, untuk mengetahui bagaimana mengelola barycentre yang tepat sangat penting, karena itu dimana ada titik seluruh massa dan berat tubuh manusia berkumpul, sama halnya dengan beladiri karate (Gianino, 2011).

Dari kedua penelitian terdahulu yang berhubungan dengan penelitian ini, penelitian yang terdahulu memperkuat penelitian yang telah dilakukan oleh peneliti, sehingga dapat bahwa model latihan yang memiliki keseimbangan, terdapat pembagian setiap variasi latihan yang dilakukan, serta penggunaan gaya mengajar yang berbeda dan tepat pada saat latihan. Untuk meningkatkan teknik dasar tendangan mawashi-geri beladiri karate didapatkan banya hal yang bisa dilakukan seperti halnya yang dilakukan oleh dua penelitian sehubungan dengan penelitian terdahulu. 


\section{Simpulan}

Berdasarakan hasil penelitian yang telah dilaksanakan peneliti memperoleh hasil persentase peningkatan keterampilan tendangan mawashi-geri beladiri karate dari siklus satu dan siklus dua mulai pertemuan pertama sampai pertemuan terakhir. Dapat disimpulkan bahwa menggunakan metode drill dengan berbagai model latihan dapat meningkatkan keterampilan teknik dasar tendangan mawashi-geri beladiri karate bagi karateka Inkado denbekang Mojokerto. Sehingga dalam program latihan ini mulai dari siklus satu sampai siklus dua terdapat tingkatan kesulitan yang bertahap untuk memudahkan dalam pembenaran gerakan tendangan mawashi-geri yang benar.

\section{Ucapan Terima Kasih}

Penulis Jurnal ilmiah mengucapkan banyak terimaksih yang sebesar-besarnya kepada Universitas Negeri Malang, Fakultas Ilmu Keolahragaan dan juga pihak dari Jurusan Pendidikan Jasmani, Kesehatan dan Rekreasi yang sudah membantu menjadi Peer-Revievwers dalam penerbitan Jurnal ilmiah tahun 2020-2021. Terimakasih penulis sampaikan kepada para dewan yang sudah membantu ikut sertaan dalam penebitan jurnal ilmiah tersebut.

\section{Daftar Rujukan}

Andayani, T. N. 2017, Efektivitas Model Latihan Drill Untuk PeningkatanTeknik Mawashi-Geri Karate-Ka Di Dojo Cakrawala Kota Malang. Skripsi tidak diterbitkan. Malang: FIK Universitas Negeri Malang.

Diyanto, R. 2019. Meningkatkan Efektivitas dan Hasil Belajar Lempar Turbo Menggunakan Metode Latihan

Bermedia Shuttle Cock Pada Siswa Kelas V SD NEGERI IV Pare, Kecamatan Selogiri, Kabupaten Wonogiri Semester 1 Tahun Pelajaran 2015/2016. KONVERGENSI,

Effendi, A. R. 2015. Hubungan Latihan kekuatan Otot Lengan dan Panjang Lengan Terhadap Kemampuan Service Atas Permainan Bola Voli. Jurnal Pendidikan Olahraga.

Gianino, C., \& Gianni, A. 2011. Physics Of Karate Project. Measurement Human Body Barycenter. Lat. Am. J. Phys. Educ.

Harumi. 2018. Penggunaan Metode Drill Untuk Meningkatkan Motivasi dan Kemampuan Bercerita Didepan Kelas Pada Siswa Kelas VII I SMP Negeri 6 Wonogiri Semester Genap Tahun Ajaran 2016/2017. KONVERGENSI.

Harun, M. F. Januarto, O. B., \& Wahyudi, U. 2017. Pengembangan Model Latihan Jump Shoot Untuk Peserta Ekstrakulikuler Bolabasket SMA Negeri 1 Kauman Kabupaten Tulungagung. Gelangga Pendidikan Jasmani Indonesia.

Hutanty, E. \& Eka, P. U. T. R. I. E. 2013. Pengaruh Latihan Walking Lunges Terhadap Tendangan Mawashi Geri Pada Cabang Olahraga Karate Pada Anak Usia 11-14 Tahun di Dojo Aspol KPPP Benowo Surabaya. Jurnal Prestasi Olahraga.

Kurniawan, A. W. 2014. Pengembangan Pembelajaran Judo Teknik Bantingan Kyu 4 Dengan Media VCD Untuk Pejudo PJSI (Persatuan Judo Seluruh Indonesia). Pertemuan Ilmiah Ilmu Keolahragaan Nasional.

Leiman, A. 2016. Karate Project Management 7 Bodies of Knowledge. Jakarta: PT Gramedia Pustaka Utama

Lumintuarso, R. 2013. Teori Kepelatihan Olaharaga. Jakarta: Kementerian Pemuda dan Olahraga.

Majid, A. 2015. Strategi Pembelajaran. Bandung: PT Remaja Rosdakarya.

Manullang, J. G., \& Tambunan, G. K. 2020. The Effect of Drill Exercise Against Speed Kick of Mawashi-Geri on Karateka Extracurricular at SMP Negeri 4 of Palembang. In International Conference on Science and Education and Technology (ISET 2019) Atlantis Press.

Nenggar, A. H. 2014. Analisis Gerakan Tendangan Mawashi-Geri Cabang Olahraga Karate Pada Atlet Forki Kabupaten Jombang. Bravo's Jurnal.

Pion, J., J. Fransen., V. Segers. 2014. The Value of Non-Sport-Specifc Characteristics for Talent Orientation in Young Male Judo, Karate and Taekwondo Athletes. Arch Budo. 
Pratuningtyas, N. N. 2017, Meningkatkan Keterampilan Mawashi-Geri Dengan Variasi Latihan Dynamic Balance Pada Ekstrakulikuler Karate SMA Negeri 1 Tumpang. Skripsi tidak diterbitkan. Malang: FIK Universitas Negeri Malang.

Purba P. H. 2017. Hubungan Kelentukan dan Kelincahan Terhadap Kecepatan Tendangan Mawashi Gery Chudan Pada Karateka Perguruan Wadokai Dojo Unimed. Jurnal Prestasi.

Riyadi, D. N. 2018. Pengaruh Latihan Stability Ball Core, Core Stability Dan Keseimbangan Terhadap Tendangan Ura Ushiro Mawashi Geri (Studi Eksperimen Pada Atlet Karate Kota Bekasi). Indonesian Education, Management and Sports Anthology.

Sudijono, A. 2015. Pengantar Statistik Pendidikan. Jakarta: PT Rajagrafindo Persada.

Suyanto \& A. Jihad. 2013. Menjadi Guru Profesional. Jakarta: Esensi.

Talib, S. E. S. (2018). Pengaruh Metode Latihan Drill Terhadap Kecepatan Mawashi-Geri Pada Kohai Dojo Inkado Kodim 1304 Kota Gorontalo. Skripsi diterbitkan. Gorontalo: Universitas Negeri Gorontalo.

Wijaya, R. S. 2015. Analisis Biomekanik Tendangan Karate Yoko Geri Kekomi (Studi pada atlet dojo karate Mahameru Jombang). E-journal.

Zetaruk, M. N., M. A. Violn., D. Zurokowski., L. J. Micheli. 2000. Karate Injuries in Children and Adolescents. Accident Analysis \& Prevention. 